\title{
A Divided Government, an Ideological Parliament, and an Insecure Leader: Turkey's Indecision about Joining the Iraq War*
}

\author{
Zeynep Taydaş, Clemson University \\ Ozgür Özdamar, Bilkent University
}

Objectives. On March 1, 2003, the Turkish parliament rejected a government motion that would involve Turkey in the Iraq war and allow U.S. forces to use Turkish territory in an offensive against Iraq. This decision has been considered as a significant departure from traditional Western-oriented Turkish foreign policy. We investigate the reasons behind this rather unexpected foreign policy decision. Method. To systematically examine the decision-making process and the outcome, we utilize the "decision-units framework." We present primary and secondary evidence from government and media sources and utilize interviews conducted with some of the high-level decisionmakers that were involved in decision making at the time. This article combines traditional methodological tools, such as elite interviews and process tracing, with novel approaches in foreign policy analysis studies. Results. The nature of the decision-unit, decision-making rules, the extraordinary circumstances surrounding the AKP (Adalet and Kalkinma Partisi-Justice and Development Party) leadership, and the absence of a strong and decisive leader shaped the outcome. Conclusion. The Turkish parliament's decision on its role in the Iraq war is an interesting and informative case for foreign policy studies. It challenges the conventional wisdom on parliamentary influence in foreign policy making in parliamentary regimes. Under certain circumstances - even when a single-party enjoys parliamentary majority — parliaments can be major players in foreign policy decision making.

During the Cold War, Turkey, as the guard of NATO's southern flank and a close ally of the United States, was a key contributor to the security of Europe. As a regional middle power of geostrategic importance, Turkey served as a buffer against Soviet expansion into the Middle East and the Mediterranean and Turkish armed forces received a great deal of equipment and financial assistance from the United States. During this period, Turkish governments

*Direct correspondence to Özgür Özdamar, FEASS, Bilkent University, 06800, Ankara, Turkey ozgur@bilkent.edu.tr. Özgür Özdamar shall share all data for replication purposes. We thank Binnur Özkeçeci-Taner, Esra Çuhadar-Gürkaynak, and the anonymous reviewers of SSQ for their helpful comments on earlier drafts. We also thank Matthew Wilson for his research assistance. Please note that the name ordering is reverse alphabetical and does not denote unequal contribution. 
refrained from active foreign policy initiatives and conducted passive foreign policy using traditional approaches ${ }^{1}$ (Aydin, 2003; Rustow, 1989). After the fall of the Soviet Union, Turkish foreign policy acquired a more independent, assertive, and active tone. Despite this change, close alliance with the United States continued throughout the 1990s and Turkish foreign policy remained as predictable as the preceding four decades. Turkey joined the coalition against Iraq in 1991, cooperated with the United States in the Balkans, the Middle East, and in post-Soviet space against Russian and Iranian influences (Özcan and Özdamar, 2009). Turkey also improved its relations with the European Union, receiving candidate status in 1999. Then, in 2003, Turkish foreign policy took a surprising and rather unexpected turn.

On March 1, the Turkish parliament voted not to approve a bill that would have involved Turkey in the Iraq war and allowed U.S. forces to use Turkish territory in the offensive against Iraq. ${ }^{2}$ Despite governing party (AKP, Adalet ve Kalkinma Partisi-Justice and Development Party) leader Recep Tayyip Erdoğan's desire to cooperate with the Bush administration and approve the bill, 97 AKP deputies went against Erdoğan's preferences and swayed the vote. ${ }^{3}$ This decision was considered a significant departure from traditional Western-oriented Turkish foreign policy. ${ }^{4}$

Why did the parliament refuse to ratify the cabinet's decision, which was based on an agreement between the governments of United States and Turkey? To answer this question, we systematically examine Turkey's decision-making process and its foreign policy outcome by utilizing the decision-units framework developed by M. Hermann, C. Hermann, and Hagan (Hermann et al. 2001). This framework is a theoretically rich and eclectic approach used to analyze complex foreign policy decisions. It provides the necessary tools to understand under what conditions certain kinds of foreign policy outcomes, such as compromise or consensus, emerge. We present primary and secondary evidence from government and media sources and utilize interviews conducted with high-level decisionmakers of the time. This article combines traditional methodological tools (e.g., elite interviews, process tracing) with novel approaches in foreign policy analysis.

Parliament's decision regarding the Iraq war is an interesting case for students of foreign policy in democracies. In parliamentary regimes, foreign policy making is expected to be dominated by prime ministers and cabinets.

\footnotetext{
${ }^{1}$ An important exception to this is the Cyprus problem and the Turkish intervention on the island in 1974.

${ }^{2}$ In Turkish literature, this process is also known as "the March 1 motion" or "the March 1 decision.”

${ }^{3}$ Turkey's decision came as a shock to the American public, who had long taken Turkish support for granted (Rubin, 2005). It had a significant impact on U.S. war plans and generated serious doubts about the future of the "strategic partnership" between the United States and Turkey (Güney, 2005).

${ }^{4}$ Since 2003, Turkey has pursued a relatively autonomous foreign policy, and improved its relations with regional actors such as Iran, Syria, and Lebanon, as well as with groups such as Hezbollah and Hamas (Özcan and Özdamar, 2010).
} 
Parliaments tend to play a minimal role, usually rubberstamping the decisions of the government. Only in extraordinary circumstances do they challenge the executive on foreign policy matters. Turkey's Iraq war decision was a rare case where the Turkish Grand National Assembly played a decisive role in the making of foreign policy. This case constituted a major departure from political traditions in Turkey, where Prime Ministers traditionally exercise strict control over the governing party's members of parliament (MPs). Despite the fact that the AKP had enjoyed a legislative majority since the 2002 elections, the legislature failed to support the government's bill (Kesgin and Karboo, 2010). This outcome is completely at odds with common wisdom - single-party governments tend to have a great deal of control over foreign policy issues (Maoz and Russett, 1993). These two rather unusual features make the March 1 decision an interesting case for students of foreign policy. A careful application of the framework to this case explains a great deal about the formulation of Turkish foreign policy decisions, especially in challenging coalition decision-unit settings, in which there are multiple politically autonomous actors.

Decision making in coalition settings often results in lopsided compromises or deadlocks. ${ }^{5}$ The Turkish case supports this argument and provides much information with regard to the factors and processes that lead to a lopsided compromise. This analysis demonstrates that the decision-making process in this case was highly politicized and complex. The extraordinary political circumstances in Turkey in early 2003 , combined with strong public opinion, and the absence of an actor capable of building consensus prevented Turkey's direct involvement in the war.

In the following section, we offer a brief overview of the decision-units approach. Next, we apply the decision-units framework to the Turkish case. That section identifies the foreign policy problem and the occasion for decision, determines the decision-making units, and discusses the dynamics of the decision-making process and the process outcome. In the last part, we discuss the importance of leadership in foreign policy making and present our conclusions.

\section{Theoretical Approach: The Decision-Units Framework}

The decision-units framework was developed to incorporate existing foreign policy decision-making models ${ }^{6}$ into a contingency model (Hermann, 2001). ${ }^{7}$ It offers important insights into the foreign policy-making process and conditions that lead to the emergence of certain types of foreign policy outcomes. The primary goal of this framework is "to identify the theoretical

\footnotetext{
${ }^{5}$ Here, we refer to "a coalition of multiple autonomous actors" in general, including (but not limited to) coalition governments.

${ }^{6}$ These models focus on group dynamics, bureaucratic and governmental politics, leadership styles, coalition politics, and strategies for dealing with domestic opposition (Hermann, 2001).

${ }^{7}$ For a complete list of the works that contributed to the development of the model, see Hermann (2001).
} 
FIGURE 1

Process Stages of the Decision-Units Framework

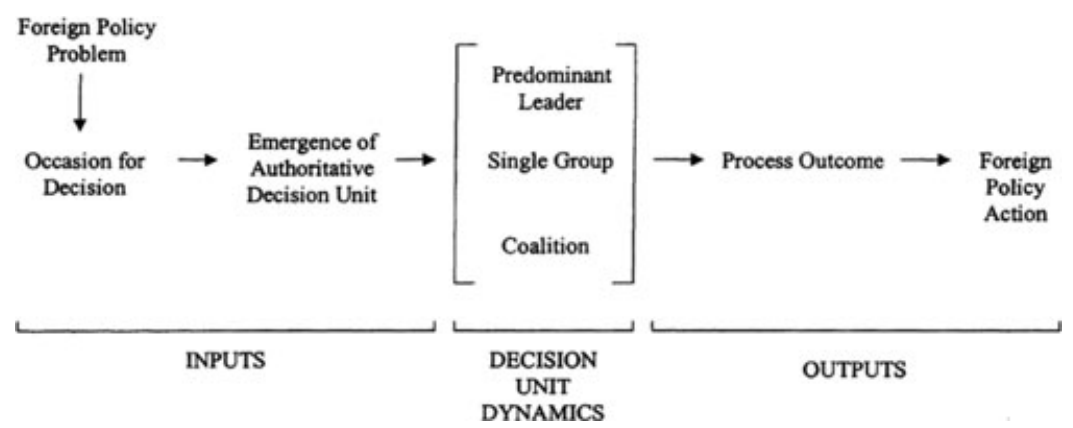

NOTE: Adopted from Hermann (2001:51).

conditions under which a set of decision dynamics is more likely to occur" and to "specify the variables that lead to one particular process as opposed to others" (Hermann, 2001:49). Instead of choosing one model over another or treating them as separate frameworks in explaining decisions, the decision-units approach finds merit in all decision-making models (such as group thinking and bureaucratic politics) and operates under the assumption that "all models will apply in certain, specific conditions".

We use the decision-units framework for a number of important reasons. First, this approach utilizes various insights from the literature and combines different decision-making approaches in a systematic manner. Second, it allows researchers to open the "black box" of decision making and understand under what conditions (i.e., kinds of political structures, situations, and problems) certain types of foreign policy behaviors take place. The framework highlights the roles of the actors in the decision unit and emphasizes that the actions of the unit are "contingent on a set of key factors that help to specify the relevance of the immediate international situation and the political context within and outside the government" (Hermann, 2001:75-6). This framework makes it possible for scholars to examine foreign policy decisions in countries other than the United States (such as Turkey), which in turn allows them to generalize about foreign policy decision-making processes in different settings. ${ }^{8}$ The decision-units approach is a valuable tool for examining the process behind Turkey's March 1 Iraq decision, but it is not "a replacement for systemic or domestic explanations of foreign policy analysis" (Çuhadar-Gürkaynak and Özkeçeci-Taner, 2004:68).

The framework has three stages, as summarized in Figure 1. ${ }^{9}$ The first two stages constitute the inputs of the framework and the decision-unit dynamics;

\footnotetext{
${ }^{8}$ For an example, see Çuhadar-Gürkaynak and Ozkeçeci-Taner (2004).

${ }^{9}$ We offer a brief overview of the framework here. For a more detailed discussion, consult Hermann (2001).
} 
the last stage is the output part of the process and includes the process outcome and foreign policy action.

The focus in the first stage is on the trigger, or so-called "occasion for decision," which requires decisionmakers to recognize that there is an issue at hand and formulate a response to deal with it. The second part of the input stage is to determine the decision unit that will have the ultimate authority to respond to the occasion for decision. The decision unit is defined as an individual (or set of individuals) who has the ability to commit the country's resources and the authority to make a decision that cannot be readily reversed (Hermann, 2001:48). The framework identifies three types of possible authoritative decision units: predominant leader, single group, and a coalition of multiple autonomous actors. ${ }^{10}$ Appendix A provides detailed information on how to select the decision unit.

When a predominant leader is the decision unit, he or she should be able to repress all dissent and have the sole authority to make decisions. In the case of a single group, a group of individuals is responsible for dealing with the problem and they collectively make the decision in consultation with each other. When the decision unit is a coalition of multiple politically autonomous actors, the decision is made by two or more separate actors together (e.g., separate individuals, groups of policy makers, interest groups, bureaucratic agencies, or members of institutions). Although none of these actors is capable of making the decision alone and forcing others to comply, some or all of them should concur before they act for the government and commit resources.

The second stage identifies the dynamics of the decision unit, including decision rules, procedures group conflicts, and alternative decision processes. The key contingencies in each type of decision unit are evaluated because these factors affect what happens in the foreign policy-making process. They "set into motion alternative decision processes" and lead to differences in the operation of the decision unit (Hermann, 2001:52).

The last stage in the framework analyzes process outcomes, that is, the actual foreign policy decisions made and actions taken by the authoritative decision unit in response to a trigger. This stage establishes links between alternative decision processes and particular outcomes and explores the content of the foreign policy decision. The framework identifies six possible process outcomes (concurrence, one party's position prevails, mutual compromise/consensus, lopsided compromise, deadlock, and fragmented symbolic action; Hermann, 2001). (See Figure 2 later in the article.)

In the next section, we apply the decision-units framework to Turkey's March 2003 decision about the Iraq war. Figure 3 shows the stages of the framework in this case.

\footnotetext{
${ }^{10}$ For more on this topic, see Hermann, Hermann, and Hagan (1987) and Hermann and Hermann (1989).
} 
FIGURE 2

Characteristics and Implications of Process Outcomes

\begin{tabular}{lll}
$\begin{array}{l}\text { Range of } \\
\text { Preferences } \\
\text { Represented } \\
\text { in Decision }\end{array}$ & \multicolumn{1}{c}{ Dymmetrical } & \multicolumn{1}{c}{ Distribution of Payoffs } \\
\hline One Party's & $\begin{array}{l}\text { Concurrence } \\
\text { (All own decision; see } \\
\text { decision as final; move } \\
\text { to other problems) }\end{array}$ & $\begin{array}{l}\text { One Party's Position Prevails } \\
\text { (Only one party owns decision; } \\
\text { others monitor resulting action; } \\
\text { push for reconsideration if } \\
\text { feedback negative) }\end{array}$ \\
Mixed Parties, & $\begin{array}{l}\text { Mutual Compromise/ } \\
\text { Consensus } \\
\text { (Members know got all } \\
\text { possible at moment; } \\
\text { monitor for change in } \\
\text { political context; seek } \\
\text { to return to decision } \\
\text { if think can change } \\
\text { outcome in their favor) }\end{array}$ & $\begin{array}{l}\text { Lopsided Compromise } \\
\text { (Some members own position, } \\
\text { others do not; latter monitor } \\
\text { resulting action and political } \\
\text { context, agitating for } \\
\text { reconsideration of decision) }\end{array}$ \\
$\begin{array}{l}\text { Deadlock } \\
\text { (Members know no one } \\
\text { did better than others; } \\
\text { seek to redefine the } \\
\text { problem so solution or } \\
\text { trade-offs are feasible) }\end{array}$ & $\begin{array}{l}\text { Fragmented Symbolic Action } \\
\text { (No members own decision; } \\
\text { seek to change the political } \\
\text { context in order to reconstitute } \\
\text { decision unit) }\end{array}$ \\
No Party's &
\end{tabular}

NOTE: Adopted from Hermann (2001:72).

FIGURE 3

Application of Decision-Units Model to Turkish Case

Occasion for decision

Triggering event: Bush administration's communication to Turkish government about military offensive against Iraq and the 'Northern Option'

Emergence of authoritative decision unit

Main decision unit: Coalition of politically autonomous actors

Dynamics of decision unit/decision making process

Rules governing the coalition favored majority - minimum connected wining coalition

Process outcome and foreign policy action

Lopsided Compromise; rejection of the government motion by the parliament.

\section{Application of the Decision-Units Framework}

\section{The Foreign Policy Problem and the Occasion for Decision}

During the summer of 2002, the Bush administration shifted its attention from the Taliban in Afghanistan to Saddam Hussein and his Ba'athist 
regime in Iraq. The United States emphasized the problems associated with Iraq's defiance of UN resolutions and accused Hussein's regime of transferring weapons of mass destruction to terrorist organizations such as Al-Qaeda. In July 2002, war plans were leaked and the possibility of a "northern front"-by which Turkey would be directly involved in the war-was mentioned for the first time (Brown, 2007). ${ }^{11}$

Turkish foreign policy makers were facing a possible U.S.-led military offensive against neighboring Iraq. When U.S. Deputy Secretary of Defense Paul Wolfowitz visited Turkey in mid-July to meet with Turkish Prime Minister Bülent Ecevit and Chief of General Staff Hüseyin Kıvrıkoğlu, he clearly conveyed President Bush's determination to intervene, although did not disclose the exact timetable. This meeting was the "trigger" for Turkey but the actual decision over its involvement fell to a new government, which took power in late November 2002. The government had to decide whether Turkey should reject U.S. war plans entirely or side with the United States, offer conditional support, and have some influence over the developments in Iraq.

\section{Determining the Authoritative Decision Unit}

The next step in analyzing the decision-making process is to determine the authoritative decision unit. Turkish foreign policy making has typically involved great caution and a search for consensus on controversial and salient issues. The process has usually been dominated by the prime minister, ${ }^{12}$ the cabinet, and the National Security Council. ${ }^{13}$ Decisions are rarely made by the president, but in times of crisis and for crucial decisions — such as the Cyprus intervention, the fall of the Soviet Union, and the Gulf War - the government must consult with other principal actors and groups, such as the Ministry of Foreign Affairs, ministries related to the decision at hand (such as the Ministry of Defense), and the Turkish General Staff. ${ }^{14}$ In Turkey, where the military has historically been highly involved in political decisions, its consent has been especially important if the decision has a security dimension, such as using Turkish bases and deploying Turkish troops abroad.

The U.S. decision to launch a military offensive against Iraq was of paramount significance to the Turkish government. At this time, there was no single individual who could be the "predominant leader." Although the prime

\footnotetext{
${ }^{11}$ See Erik Schmitt (2002a, 2002b) for more information.

${ }^{12}$ According to Turkey's constitution, the cabinet, headed by the prime minister, is the main entity responsible for devising basic foreign policy goals and principles.

${ }^{13}$ The National Security Council of Turkey includes the president, the prime minister, the top command of the Turkish Armed Forces (TAF), and some ministers. Its main responsibility is to advise government on security matters. See Özcan (2001) for the role of the military in foreign policy making.

${ }^{14}$ For more information about the actors involved in foreign policy making, see ÇuhadarGürkaynak and Özkeçeci-Taner (2004), Tayfur and Göymen (2002), Kardaş (2006), and Makovsky and Sayari (2000).
} 
ministers, first Ecevit and then Gül, were heads of the government and responsible for formulating foreign policy, neither qualified as a predominant leader; they did not have the authority to commit government resources and their decisions were not irreversible by another entity within the political system. Like all Turkish PMs, they legally were constrained by other actors, especially parliament. President Ahmet Necdet Sezer did not (and really, could not) act as a predominant leader either. He did not assume an active role in the Iraq war decision but all other actors within the decision unit were aware of his opposition to Turkish involvement.

This article argues that the authoritative decision unit at the time was a coalition of politically autonomous actors. Although the cabinet had been involved in the problem since the outset and was responsible for handling the issue, it was not the dominant decision-making group. Article 92 of the Turkish constitution requires parliamentary authorization to dispatch Turkish troops abroad and deploy foreign troops on Turkish soil ${ }^{15}$ (Efegil, 2001). Unlike many other foreign policy decisions, the Iraq war decision could thus not be made by the executive organ alone. Legally, all cabinet members and a parliamentary majority had to approve Turkey's involvement. Politically, the government needed to garner support from the president and the Turkish armed forces (TAF) during National Security Council meetings. Figure 4 shows the formal procedure of decision making in Turkey as it pertains to the use of force (and the use of Turkish soil by foreign troops). Legislation requires the prime minister to work with the president and the National Security Council in policy consultation. The Ministry of Foreign Affairs is responsible for assisting the minister of foreign affairs and the prime minister. After consultation, the cabinet formulates the details of the policy and prepares a bill that must be approved by a majority in parliament in order to pass.

In coalition decision-unit settings, foreign policy decision making "is very fragmented and centers on the willingness and ability of multiple, politically autonomous actors to achieve agreement to enact policy" (Hagan et al., 2001:169). Reaching an agreement can be a challenging task-the actors in coalition decision units must play a careful two-level game (Putnam, 1988). Individual players in the unit are severely constrained by their constituency, internal dynamics, and the domestic political environment, as well by as external pressures. This situation requires ongoing bargaining and negotiation with opposing actors within the decision unit (Hagan et al., 2001). In such a process, having a parliamentary majority is a real advantage. Even then, for the bill to pass, governments must ensure that the members of the ruling party (or parties) vote in a unified way.

At the time of voting on the Iraq issue, the AKP had sole control of cabinet and two-thirds of the seats, while the main opposition party, the CHP

\footnotetext{
${ }^{15}$ One exception to this rule is for international treaty obligations, such as to NATO. The other exception is if the country were under attack and parliament were not in session, the president could authorize the use of force.
} 
FIGURE 4

Turkish Foreign Policy Decision Making (as it pertains to the use of force abroad, use of Turkish soil by foreign troops)

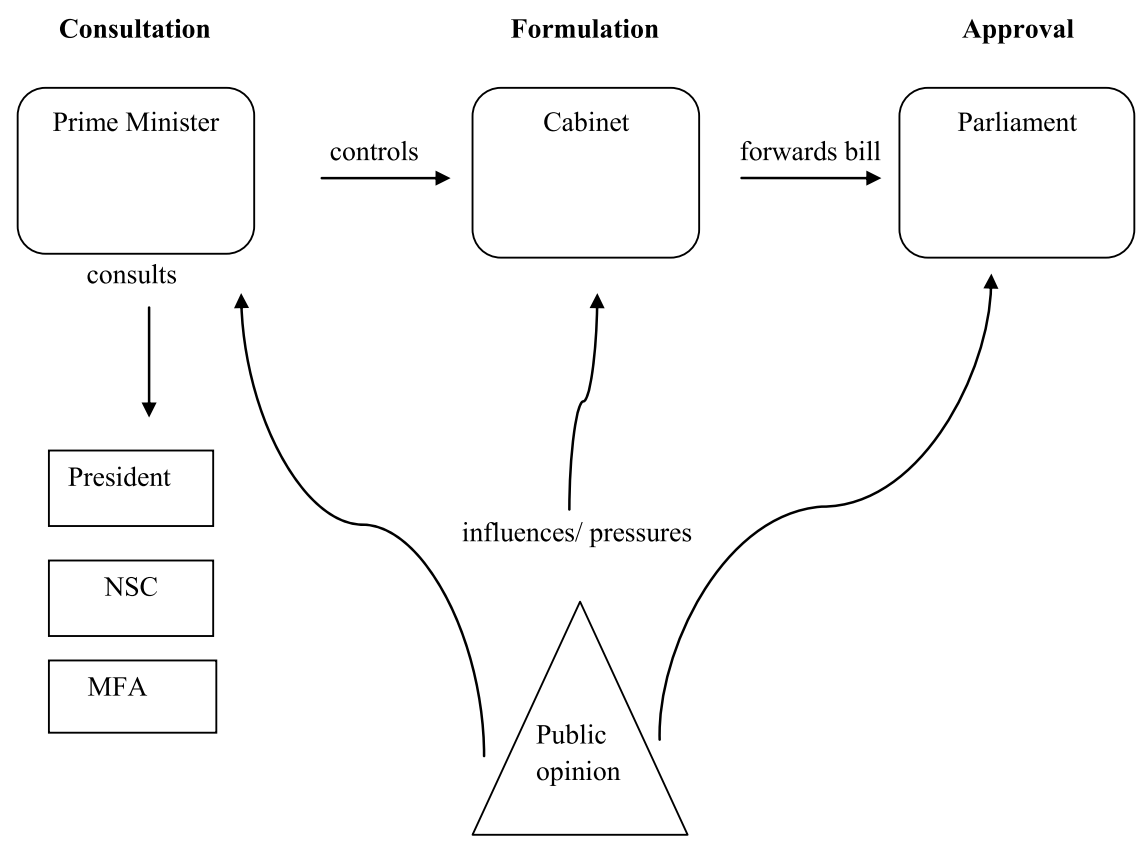

(Cumburiyet Halk Partisi - the Republican People's Party), held a third of the seats and was the only opposition party in parliament. Although insulated from parliamentary overthrow, the AKP was heavily fragmented and did not have strong leadership until late March 2003, when Erdoğan was finally elected. The AKP's charismatic leader, Tayyip Erdoğan, was legally banned from running in elections. Prime Minister Abdullah Gül led the first AKP government from December 2002 to mid-March 2003, until the law preventing Erdoğan from running was changed and he was elected in a by-election. The Turkish parliament's decision to reject the government's motion to participate in the Iraq war should be evaluated within this broader political context.

\section{Dynamics of the Decision-Making Process}

Fragmentation of political authority is a defining feature of coalition decision units. No single actor has the power and authority to commit state resources and enact a policy initiative on its own (Hagan et al., 2001). The key contingency variable that influences the decision-making process in the coalition decision-unit setting is the "decision-making rules." These rules "shape the political interactions within the decision unit" and "define the 


\section{FIGURE 5 \\ Turkish Decision Making Within the "Coalition of Multiple Politically Autonomous Actors"}

Decision making in a coalition decision unit

Well established and institutionalized rules for decision making and information certainty concerning the roles of each player
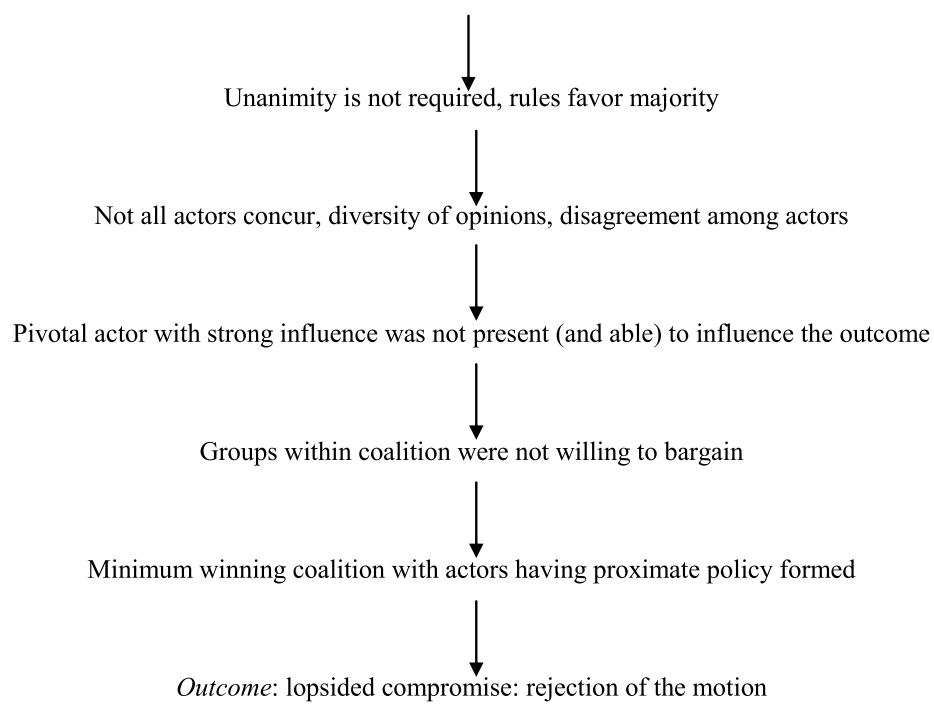

context within which the process of achieving agreement occurs" (Hagan et al., 2001:178). According to Hermann (2001) and Hagan et al. (2001), there are three types of decision rules: (1) an anarchy model (where there are no established rules for decision making); (2) a unit veto model (where decision rules require unanimity and any actor can block the initiatives of others); and (3) a minimum connected winning coalition (where the coalition rules favor the majority).

As Figure 5 indicates, at the time of the Iraq decision in Turkish politics, the governing decision rule within the coalition of multiple actors favored majority rule, which allowed an authoritative decision to be made by a subset of actors within the decision unit. Although consensus among the cabinet, parliament, president, and the National Security Council would have been ideal, it was possible to form policy with the support of only some of those actors. The Iraq policy was formed by the prime minister and the minister of foreign affairs, in consultation with the president and the National Security Council. Then, the motion had to be approved unanimously by the cabinet and next by the majority of the parliament. There was great deal of "information certainty" 
with regard to the political process, indicating that decision-making procedures were clear and well established (Hagan et al., 2001).

The Iraq war posed an extraordinary challenge to Turkish decisionmakers. It was difficult for Turkey — as a regional middle power- to resist the demands of the superpower United States. The United States had been a long-time strategic ally and it was in Turkey's best interests to have the United States on its side in such a tumultuous region as the Middle East. Turkey was highly concerned about Kurdish movements in and out of Turkey. To fight against the PKK (Kurdistan Workers Party) and prevent an independent Kurdistan in its back yard, many top Turkish decisionmakers thought they needed to cooperate with the United States. In light of the Iran-Syria alliance that had supported the PKK during the 1980s and 1990s, maintaining relations with the United States appeared to be a good choice (James and Özdamar, 2009; Özcan and Özdamar, 2010). Policy makers were also aspiring about Turkish firms' possible involvement in rebuilding Iraq after the war.

Many actors and Turkish decisionmakers, opinion formers and the public, however, perceived the American-led invasion as a threat to security and stability in the region, and therefore opposed the war. In 1991, the United States had promised to compensate Turkey for the serious losses in oil pipeline revenues, trade, and tourism it had suffered during the first Gulf War. In the end, however, little aid was delivered. Turkey's economy was still fragile and many Turks were thus concerned about the potential negative economic impacts of a second war. There were also potential political repercussions. After the imposition of a no-fly zone in the first Gulf War, a power vacuum emerged in Northern Iraq. This vacuum allowed different Kurdish groups to operate independently from the center and conduct terrorist activities on Turkish territory. As a result, the number of terrorist incidents in Turkey increased (Özcan, 1999). That situation also increased the possibility of an independent Kurdish state in Northern Iraq, although it never emerged. Turkey was concerned that a new U.S. invasion would lead to a civil war between Kurds and Sunni Arabs, a refugee flood into Turkey (as had happened in the first Gulf War), and an independent Kurdish state next door. Such developments would jeopardize Turkey's territorial integrity and have devastating consequences for the country in the long run (Güney, 2005; Gözen, 2005; Kardaş, 2006).

The most preferred policy for Turkish leaders regarding Iraq was to prevent war through a diplomatic solution and preserve its territorial integrity. Hence, both Ecevit's coalition and the subsequent AKP government worked hard to prevent a U.S.-led invasion. Yet, when it became clear that invasion was inevitable, Turkish decisionmakers decided to cooperate with the United States to have a better chance of protecting Turkish national interests. ${ }^{16}$ In

\footnotetext{
${ }^{16}$ Authors' interview with then-Minister of Foreign Affairs Yaşar Yakış (March 7, 2008). Yakış stated that "We are participating in a war that we cannot espouse, a war that our public does not support. But we cannot stay out of it. It is necessary that we support the Americans" (Yetkin, 2004:112).
} 
other words, the goal of this rather "unwanted cooperation" with the United States was to minimize political and economic damage and play a meaningful role in the reconstruction of Iraq after the war. To accomplish these goals, important figures in the government, including Prime Minister Gül, Minister of Foreign Affairs Yakış, and AKP leader Erdoğan, held numerous meetings with their U.S. counterparts to discuss the parameters of Turkish cooperation. Because of the tremendous U.S. pressure on Turkey to participate, the Turkish government asked for assurances regarding Iraq's territorial integrity and on preventing future instability in the region. Turkey also attempted to secure a financial aid package to buffer against the predicted economic consequences.

An agreement was reached in late February 2003. A total of 62,000 American troops would be stationed in Turkey, and Turkey would deploy 30,000 soldiers in coordination with the United States to Northern Iraq. The United States received privileges to use Turkish airports and seaports for military operations. It reiterated its commitment to the unity of Iraq and promised to limit military aid to Iraqi Kurdish groups. In return for its support, Turkey was offered a financial compensation package including $\$ 2$ billion in aid and $\$ 24$ billion worth of loan provision (Bölükbaşı, 2008). The proposal was perceived by the Turkish government as a "good" one because it gave Turkey many advantages, including the right to carry out operations against the PKK in Northern Iraq. And even though Turkish decisionmakers accepted the United States offer reluctantly, few people in the AKP leadership expected the motion to fail (Yetkin, 2003).

Although the agreement was signed, not all actors in the decision unit approved of it. While most cabinet members seemed to agree with providing conditional support to United States, others emphasized the lack of international legitimacy and the costs of direct Turkish involvement. Some actors, such as the TAF, remained silent and did not support any course of action. A discussion of each actor's policy position follows.

The first actor in the decision unit was the AKP — the ruling party. At the time, it was a new party and most members-who had little experience in governing - had come from other right-wing parties. When the Constitutional Court of Turkey banned several Islamist parties during the late 1990s, a faction of the pro-Islamist Virtue Party, who called themselves "reformists" (in Turkish, yenilikçiler), established a socially conservative, pro-West and pro-EU party. Although the top leadership mostly included pro-Islamist politicians, the party also recruited members from the center-right ANAP (Anavatan Partisi-Motherland Party), the DYP (Dogru Yol Partisi-True Path Party), and the nationalist MHP (Milliyetci Hareket Partisi-Nationalist Movement Party). In rare cases, the AKP has attracted members from secular left-leaning parties such as the DSP (Demokratik Sol Party-Democratic Left Party) and the CHP. In addition to formal political parties, the AKP has been supported by religious movements (cemaatler, in Turkish), such as Nakşi or Gülen. Like many other catch-all parties, the AKP was founded as a coalition of mixed political and social views. 
Although this background has helped the AKP win successive elections since 2002, it proved difficult for them in the Iraq war decision. That issue reflected the ideological divides within the party and AKP leadership experienced serious problems convincing the cabinet or the party's deputies that cooperation with the United States would benefit Turkey. An anecdote from Prime Minister Gül shows how divisive the decision was. When Gül was warned about the risk to U.S. relations unless full cooperation was achieved, he said: "I can maybe explain this to the opposition (the CHP), but not to my own party" (Yetkin, 2004:117). Gül was referring to the incompatibility of the war decision with the AKP's conservative norms; it was especially difficult for them to convince the party's pro-Islamist deputies, who were being seriously pressured by the Islamist conservative media, intellectuals, and constituencies not to participate in the war. ${ }^{17}$ The pro-Islamist wing garnered support from some of the AKP's top administration, such as Speaker of the Parliament Bülent Arınç, who was strongly against the motion (Yanatma, 2008).

The AKP attempted to share the responsibility for the decision with other domestic actors. In an attempt to induce support from the military, Gül moved the parliamentary vote to after the February 28, 2003, National Security Council meeting. Of all the Turkish actors, the issue most affected the military, but surprisingly, the TAF offered no recommendations to the government and suggested the motion be taken to parliament. According to one of the most experienced journalists in Ankara politics, that meeting was perhaps "the only one in history" that produced no advice or comment on an important issue (Yetkin, 2004:169). Some reports stated that the Turkish military wanted to control Northern Iraq to secure Turkish interests but they had objections to allowing the United States to build troops on Turkish territory.

Since the foundation of modern Turkey, the military has been directly and indirectly involved in politics and has intervened in civilian governments' decisions on several occasions. Given this background, the TAF's silence on the Iraq war issue was unusual and requires further discussion. Experts on civil-military relations in Turkey suggested a few reasons why the TAF chose not to play an assertive role during the process. ${ }^{18}$ First, there was an important change in military leadership in August 2002, when General Hilmi Özkök was appointed Chief of General Staff. Özkök's “westernized” views on civilmilitary relations differed from his predecessors'; he felt the military should not intervene in civilian politics. Apparently, there were grave differences between Özkök and other top generals regarding this belief. Playing a two-level game, General Özkök suppressed those generals and resisted government pressure to support cabinet's decision to join the war. Through his actions, Özkök helped build the first truly democratic example of civil-military relations in Turkey.

\footnotetext{
${ }^{17}$ Interview with then-Deputy Prime Minister Abdüllatif Şener (March 4, 2008). Şener suggests that the strongest media opposition came from Islamist and left-leaning newspapers.

${ }^{18}$ Interview with Nihat Ali Özcan, November 11, 2011. Interview with an academic expert on civil-military relations in Turkey who asked to remain anonymous, November 10, 2011.
} 
Second, opinions differed among TAF officers on the war and its possible effects on Turkey's most vital security problem, that is, the fight against the PKK. Some generals believed that joining the war would help eliminate the PKK, but others were not convinced that the United States would assist Turkey in this fight. This lack of a unified attitude toward the war and its effects on Turkey may have also prevented the TAF from acting decisively.

The third explanation suggests that the AKP's ideological background prevented the TAF from cooperating with the government. As the self-declared "protector of secularism in Turkey," the top command was not in favor of "helping and aiding the Islamist government on important issues." 19 Our interviews with AKP leaders of the time confirmed this belief. Other AKP leaders (who asked to remain anonymous) maintained that the military did not want to share the responsibility of such an unpopular and risky decision and planned to let the AKP "fall upon its face" by letting them go ahead with the motion. ${ }^{20}$ These AKP members suspected that if the motion were passed, the costs would have been so high that the AKP would not have been reelected, which was what the military establishment hoped for. The hardline secularist nature of the military and the Islamic background of the AKP might thus have prevented cooperation between the two institutions.

President Sezer was also openly against the war. He insisted that Turkey should act according to international norms; as a former judge, he insisted that a U.N. Security Council resolution was necessary to support the United States in this war, and that in its absence, Turkey should not facilitate U.S. operation by opening its air bases and borders to coalition troops. He voiced his concerns about international legitimacy on many occasions, including in National Security Council meetings.

Opposition parties typically have limited ability to influence an outcome, especially when the government enjoys a parliamentary majority. However, in the Iraq decision, the CHP played an important role. Starting from early 2002, the AKP government was in disarray over Iraq policy. Opposition members argued the Iraq war lacked legitimacy and that participating in it would equal participation in a crime. Interestingly, the hardline secularist CHP used religious rhetoric to influence AKP members against the motion. ${ }^{21}$

Public opinion also had significant influence on the decision-unit actors' behavior. ${ }^{22}$ As early as fall 2002, Turkish public opinion was strongly opposed to the war and highly critical of U.S. foreign policy in the Middle East. The majority of Turkish citizens were afraid of turmoil in Iraq and skeptical about

\footnotetext{
${ }^{19}$ Interview with an academic expert on civil-military relations in Turkey who asked to remain anonymous, November 10, 2011.

${ }^{20}$ The military was concerned about the possibility that any endorsement from it would be used by the AKP as an excuse for taking part in an unpopular war.

21 “TBMM'de Tarihi Oturum: CHP’li Sav'ın konuşması: “Bu iğrenç savaşın altında ezilmeyin.” http://www.belgenet.com/2003/sav_010303.html.

${ }^{22}$ Although policy making (domestic and foreign) is predominantly an elite affair in Turkey, the importance of public opinion in the process has increased since the late 1980s (Aydin, 2003; Robins, 2003a,2003b; Kirişçi, 2006).
} 
U.S. intentions. The United States was perceived not as a "savior," but as an "aggressor" who planned to violate the sovereignty of a neighboring Muslim country. This perception, on top of the increasing salience of religion in politics and growing identification with Islam-exemplified in the success of the AKP in the ballot box in the 2002 elections-made it difficult to convince the public to support the U.S.-led coalition ${ }^{23}$ (Brown, 2007; Gozen, 2005; Filkins and Miller, 2003). A survey by the Pew Research Center in July and August 2002 shows the strength of the opposition to war among Turks: more than 8 of 10 (83 percent) opposed the idea of allowing the United States and its allies to use Turkish bases for military action; a narrow 13 percent favored this idea. ${ }^{24}$ Less than a year later, anti-war sentiments and skepticism in Turkey had grown even more. In March 2003, 86 percent of Turks opposed the U.S.-led military action in Iraq to remove Hussein from power. Opposition in Turkey was even stronger than in Germany (69 percent) and France (75 percent). ${ }^{25}$ This percentage increased to 94 percent in Turkey as the war drew nearer (Brown, 2007). Turkish citizens appeared to differ from Europeans with regard to their assessment of the danger posed by Hussein. They were much more suspicious about U.S. actions than before the war. A slim majority of Turks (53 percent) thought that the United States wanted to get rid of Hussein as a part of a war against unfriendly Muslim countries, rather than because of the threat he posed to peace. ${ }^{26}$ This statistic increased to 60 percent in 2003.

AKP leader Erdoğan was clearly in favor of the motion being passed. Prime Minister Gül was against it, but under pressure from Erdoğan, he worked for the motion to be approved. All cabinet members signed the bill although they differed about the best way to participate. Deputies were divided in their opinions and the views of the TAF's top command were ambiguous at best. President Sezer clearly opposed the war but did not campaign against it. Despite the dissent, none of the actors within the decision unit was willing or able to play a pivotal role in the discussions.

\section{The Process Outcome}

Despite the AKP's 363-seat majority (of 550), the motion to enter the war in Iraq fell three votes short of passing. According to Turkish parliament by

\footnotetext{
${ }^{23}$ The attitude of the U.S. government during the negotiations also negatively affected public opinion. Many Turks found it insulting that Turkey was portrayed as a country interested in nothing but material gains (Bölükbaşı, 2008). See Hale (2007), Kapsis (2006), Gözen (2005), and Ozcan (2008) for more information on the impact of public opinion on the March 1 vote.

24"What the World Thinks in 2002: How Global Publics View: Their Lives, Their Countries, the World and America," The Pew Global Attitudes Project. Available online (http://people-press.org/reports/display.php3?ReportID=165).

25 "America's Image Further Erodes, Europeans Want Weaker Ties," The Pew Global Attitudes Project. Available online (http://people-press.org/reports/display.php3?PageID = 681).

26"What the World Thinks in 2002: How Global Publics View: Their Lives, Their Countries, the World and America" The Pew Global Attitudes Project. Available online (http://people-press.org/reports/display.php3?ReportID = 165).
} 
laws, a simple majority of the MPs present in the chamber is necessary to pass a motion. During this secret vote, 533 MPs were present, thus requiring 267 "yes" votes for the motion to pass. A total of 264 MPs voted in favor, 250 voted against, and 19 abstained. All CHP deputies publicly announced that they were against the motion. Of the 361 AKP deputies present, 97 members of the ruling party did not vote for the motion, including Deputy Prime Minister Ertuğrul Yalçınbayır.

Dissent within the AKP was much larger than Erdoğan expected. ${ }^{27}$ To understand the process outcome, we rely on Hermann's (2001) typology, which categorizes outcomes according to the range of preferences represented in decisions and payoff distributions. To reiterate, there are six possible outcomes: concurrence, deadlock, one party's position prevails, mutual compromise/consensus, lopsided compromise, and fragmented symbolic action (see Figure 2).

We argue that "concurrence" among actors was not a likely outcome in this case, as the decision did not represent shared preferences. Once cabinet sent the motion to parliament, it was almost impossible to reach a solution that would represent the interests of mixed parties and satisfy all group members. Despite their differing opinions, the issue was extremely important and highly salient for all actors in the decision unit; thus any deviation from their original positions was not likely.

"Deadlock" refers to a situation where no one's preferences are represented and the unit fails to reach a decision. In this case, the unit reached a decision, so this outcome does not apply. The decision, however, was asymmetrical in the distribution of payoffs, as not all parties realized their preferences. Of the three outcomes where payoffs are asymmetrically distributed, one might conclude that "one party's position prevailed." This argument is not plausible, however, because the decision was not owned by a single group.

We argue that the decision outcome was a "lopsided compromise," where one party's preference prevailed and some members gained more than others. In this case, the anti-war lobby "won" the parliamentary vote and the supporters of the motion lost. According to the typology, in a lopsided compromise "winners" yield a little and allow the "losers" to save face. The losers, on the other hand, continue to monitor events and may urge that the decision be reexamined if the desired results are not forthcoming. In other words, members of the decision unit whose preferences are not represented in the final decision can become "agitators for further action" (Hermann, 2001:71) and may keep the issue alive, push to reconsider the decision, and show how the previous policy does not achieve aims.

The bargaining and voting processes and the aftermath of the Iraq decision provide additional support for our claim that the outcome was, indeed, a lopsided compromise. First, the decision was owned and celebrated by the AKP naysayers and all the CHP deputies. Despite his initial shock, Erdoğan

\footnotetext{
${ }^{27}$ Authors' interview with Abdüllatif Şener (March 4, 2008).
} 
quickly embraced the decision and called it a "triumph of democracy." Many AKP members who voted for the motion also maintained that the democratic choices of parliament needed to be respected. Next, as expected, members of the decision unit whose positions were not reflected in the outcome kept the issue alive, demanded the decision be reconsidered, and, finally, took further action. Erdoğan and the deputies who voted "yes" in the parliament quickly became proponents of a new motion to allow U.S. planes to use Turkish airspace in their offensive against Iraq and thousands of Turkish troops to contribute to "stabilization and rebuilding" efforts in postinvasion Iraq. This new government motion was accepted in parliament on October 7, 2003, with near unanimous support from the AKP MPs. The CHP deputies did not change their position and voted "no" for this motion too. These developments were entirely consistent with the expectations of Hermann's decision-units framework.

A careful review of Hermann's theoretical argument, outlined in Figure 2, supports this conclusion. It is obvious that after the March 2003 vote denied by the parliament payoffs were assymetrical. There were the so-called "winners" and "losers" as to the war decision. Range of preferences also definitely represented "mixed" or "one party" decision to the subject. Of these two, we argue that the March 2003 vote was a "lopsided compromise" because, as Hermann suggests, some members owned the decision and some did not. Moreover, those who "lost" in March 2003 monitored the resulting action, political context, and forced for a new decision. Therefore in October 2003 PM Erdoğan and the pro-war decisionmakers brought a new occasion for decision. Had Turkey's involvement in Iraq War was limited to the decision in March 2003, the outcome could have been labeled as "one party's position prevails." Yet, due to international and some domestic pressures, "losers" of the March 2003 vote looked for opportunities for a new decision later in that year and this time they succeeded. The government received a parliamentary approval to send troops to Iraq.

\section{The Importance of Leaders in Foreign Policy Decision Making}

Based on the discussion above, we contend that the AKP leadership failed to secure approval of the March 1, 2003, motion primarily because a pivotal actor, one who is willing to assume all risks associated with his or her actions, was absent. Someone vested with authority, that is, a president, prime minister, or party leader, could have played the role of predominant leader by taking charge and overwhelming all opposition within his party, as President Ozal did in the case of the first Gulf War. Such an actor could have set the rules of the game so that cabinet found support in parliament, given that the ruling party had a majority. During the crisis, however, the AKP was in disarray and such a figure was lacking. As a result, a significant number of AKP members, as well as other actors in the decision unit, went against AKP leadership. 
In this specific foreign policy decision, parliament became the most important decision-making authority by default, simply because "the government did not show any resolve on the matter" (Keskin and Karboo, 2010:32). Although Turkish prime ministers have traditionally controlled their parliamentary groups and made their preferences prevail (no other important foreign policy decision had been taken against government preferences before March 1, 2003), legally, the final decision rested with parliament. The AKP leadership's indecisiveness combined with strong public opposition boosted the effect of parliament in the decision-making process. Prime Minister Gül did not have the influence expected from his position because Erdoğan was the acknowledged leader of the party and was anticipated to soon assume that office. ${ }^{28}$ However, given his somewhat precarious position, and because he assumed the motion would pass, Erdoğan was reluctant to adopt an assertive tone.

When faced with a crisis situation or a critical decision, powerful figures can choose to be involved in what is taking place and exercise their authority for the survival of the government or the state or not (Hermann, 2001). Some leaders take charge of any decision the government needs to make, and some are less inclined to do so. The choice largely depends on the circumstances surrounding the issue, the interest of the leader in foreign policy, and his or her expertise and experience on the issue. Under some conditions, leaders feel more comfortable exercising authority and determining the outcome. Why did Erdoğan not exert his influence over AKP deputies? What stopped him from acting like a pivotal actor? Given his strong leadership record and strict control over various foreign policy decisions since 2003, these questions are intriguing. Erdoğan, inexperienced in foreign policy and not legally the leader, preferred not to take an assertive stance on the decision, but this was largely a byproduct of the unique situation he was in at the time.

Erdoğan established the AKP in 2001 and brought it to victory in the 2002 elections, yet he could not be elected to parliament-a Turkish court had banned him from holding office after he was convicted of publicly reciting a poem that "incited religious hatred." As a result, the AKP's number two man, Abdullah Gül, was appointed prime minister. The most important item on the AKP's agenda then became amending the constitution to allow Erdoğan's election. Meanwhile, Erdoğan acted as de facto prime minister and led the Iraq war talks with the United States, even though he had no formal powers. He tried to show the members of the party that he was, indeed, in charge. His influence over the MPs remained limited, however, compared to that of a typical Turkish prime minister. The "double-headed leadership" continued until Erdoğan's political rights were fully restored, two weeks after the rejection of the motion in the parliament.

\footnotetext{
${ }^{28}$ Both ministers interviewed for this article confirmed our observation that although Gül was the Prime Minister, Erdoğan was the power broker during the policy formulation.
} 
The division in leadership had major implications for Turkish foreign policy during the Iraq crisis (Robin, 2003; 2003b). Erdoğan and Gül had different opinions about the best course of action to be followed. While Erdoğan followed a more "pragmatic" approach and supported U.S. war plans; Gül favored a more "cautious" foreign policy and a noncommittal, gradual approach. Erdoğan gave clear signs of support and cooperation but Gül was concerned about the adverse effects of Turkish participation (Kardaş, 2006). Prominent AKP figures, such as Speaker of the Parliament Bülent Arınç, supported Gül's approach. Gül and Arınç became "the voice" of AKP's Islamist, rather ideological wing.

Erdoğan wanted to cooperate with the United States for obvious reasons. For a leader who was seeking both domestic and international legitimacy, not accommodating the demands of the Bush administration-who welcomed the result of the 2002 Turkish elections-would have been a costly move. On the other hand, Erdoğan was also aware that public opinion was strongly against the war and that there was growing opposition in the AKP against joining the coalition. From an Islamist background himself, Erdoğan knew that the Iraq war and U.S. policies conflicted with the conservative constituencies that had backed him in the election. Strongly supporting the motion and pushing others to do the same would lead to a major split in the AKP and force many ministers and deputies to leave. He was afraid a domestic backlash would cost him his long-awaited office.

In the end, Erdogan chose the middle ground and gave the impression that he did not strongly support either option. He asked the government to move on with negotiations and preparations for the war, but in public, he did not strongly support the motion and hinted to MPs only minutes before the actual vote that he was in favor. ${ }^{29}$ In early February 2003, a motion passed that allowed the U.S. military to inspect Turkish seaports and airports.

On the morning of March 1, 2003, before the vote took place, Erdoğan met with the AKP MPs. In the meeting, a few MPs who favored joining the war voiced their views ${ }^{30}$ and argued that by siding with the United States, Turkey would be involved in rebuilding Iraq and gain significant advantages in fighting the PKK. Staying out of the war, they argued, would mean losing opportunities vital to Turkey's territorial integrity and unity. Under pressure from their constituencies and various NGOs, many MPs articulated negative opinions and recommended that the motion be rejected. They stated that if Turkey participated, it would seem to facilitate the invasion of a neighboring Muslim country, and this, in the long run, would hurt its relations in the region. They also stressed that it would be very difficult to explain such a decision to the public. The more conservative

\footnotetext{
${ }^{29}$ Authors' interview with Abdüllatif Şener (March 4, 2008).

${ }^{30}$ Authors' interview with two anonymous AKP MPs (March 4, 2008).
} 
Islamic wing of the party did not want to participate in a war against fellow Muslims. $^{31}$

To get a sense of the AKP MPs' inclinations, at this meeting Erdoğan asked each deputy to write down his or her preference on a piece of paper. After counting these "mock" votes and seeing that the "yes" side was likely to win, he decided not to suggest a "party decision." 32 He thought that the motion would pass by nearly 50 votes. Erdoğan was fully aware that the bill might not pass without declaring a party decision or without at least a suggestion by the leader. However, he did not want to publicly side with an operation against a Muslim country and take full responsibility for the decision. Evidence from primary and secondary resources suggests that Erdoğan wanted the motion to pass without appearing to support it himself.

In sum, before his premiership was guaranteed, Erdoğan did not want to meddle with the opposing views in the AKP. He chose to maintain a "balanced" position during the negotiations with the United States. He tried to satisfy his foreign allies (i.e., the United States) and his domestic constituency (i.e., the public), and worked to achieve his desired outcome without threatening his own position. The result was not exactly what he wanted.

\section{Conclusions}

The decision to support the U.S.-led coalition in a war on Iraq was challenging for Turkish policy makers given the immediate and long-term implications for the governing party and Turkey. Using the Hermann's decision-units framework as our base, we examined the decision-making process and identified the positions of members within the decision unit, as well as the decision rules that shaped the process and its outcome. This detailed examination of the case allowed us to reach some important conclusions about how the decision was made.

This analysis shows that the final outcome was the result of a complex game at the domestic and international levels involving the constraints of strong public opposition, internal political considerations of the ruling party, extraordinary circumstances surrounding the AKP leadership, and the absence of a pivotal actor.

For foreign policy studies, applying the decision-unit framework and analyzing the Turkish decision on its role in the Iraq war are important for a number of reasons. First, this case challenges conventional wisdom about the role of assemblies in foreign policy making in parliamentary democracies. Contrary to expectations, parliament went against the wishes of cabinet

\footnotetext{
${ }^{31}$ Authors' interview with Yaşar Yakış (March 7, 2008) and Abdüllatif Şener (March 4, 2008).

${ }^{32}$ Some AKP deputies leaked to the press that there were only 30 "no" votes when they were counted at the group meeting (Yetkin, 2004:172-73). Apparently, some MPs hid their real inclinations and failed Erdoğan.
} 
(the main policy-making authority in parliamentary settings) and played a decisive role in the decision-making process. Our case study shows that the influence of parliament in foreign policy should not be taken for granted; under certain circumstances - even when one party enjoys a parliamentary majority_parliaments can be major players in foreign policy and have a significant impact on the outcome. Further work on this topic is essential for a clear understanding of when and how parliaments influence foreign policy.

Second, this study contributes to the literature that focuses on the process of policy making as opposed to the outcome, which tends to dominate foreign policy analysis studies. Our analysis of Turkey's Iraq decision reveals the importance of the nature and composition of the decision unit. Actors in that decision unit had different positions on the issue and varying levels of influence on the outcome. Turkey's institutional structure requires a broad compromise when making decisions regarding the use of force. Although the constitution gives the prime minister an advantage over other actors when making such decisions, we have shown that the political dynamics can also exert a great deal of influence.

Examining the decision-making process in this issue illustrates that domestic politics can be as important as systemic pressures during the formation of foreign policy. Such approaches have become prevalent in foreign policy analysis studies in recent decades (Hudson, 2005). Turkey's domestic political dynamics in early 2003 played a significant role in the government's efforts to pass the legislation and parliament's decision not to approve it. The AKP government had just been formed when U.S. pressure on Turkey to join the war peaked. The party's young leadership failed to control divisions within the party, which were heightened by negative public opinion. Although prime ministers in Turkey have been capable of overcoming such difficulties in the past, Erdoğan's extraordinary legal status limited his abilities to convince opposing actors. The Turkish case confirms that decisionmakers must find a delicate balance between systemic pressures and domestic political concerns when making foreign policy decisions.

This study also supports the premise that decision rules and regulations matter in the decision-making process; they guide the interactions among various actors in the decision unit. We provided a detailed discussion of the decision-making rules in Turkey (Figure 4) as they pertain to the use of force abroad; we also showed how the rules governing the decision-making process defined the context and, in turn, set certain dynamics into action. We find strong support for Hermann's argument that "who leads matters." In other words, our findings highlight the importance of the "domineering figure" in foreign policy decision making (Brown, 2007). The absence of a pivotal actor in the Turkish case prevented party leadership from acting decisively and establishing effective control over the AKP (Kardaş, 2006). As a result, many AKP members went against government policy and voted as their constituents favored. Erdoğan's delicate place within the party, negative public opinion, 
and broad divisions within the AKP diminished Erdoğan's confidence and prevented him from pushing a controversial decision past the skeptical actors of the decision unit (Brown, 2007) to achieve a unified political stance. Had Erdoğan been prime minister at the time of the decision, he could have better influenced party deputies to a "yes" vote.

History provides support for our argument: only seven months after the March 1 vote, the Turkish parliament approved another motion to send troops to Iraq for combat purposes and help rebuild the country, this time by a large margin. The difference between the March 1 and October 7 motions is clear: the second time, Erdoğan had been prime minister for more than six months and he was not reluctant to use his position and exert his influence. In a meeting before the parliamentary vote in October 2003, PM Erdoğan told the MPs that he was in favor of the motion and that he considered this vote a "vote of confidence" on himself (Yetkin, 2004:254). Erdoğan's assertiveness worked; 358 AKP MPs, of 360 present, passed the bill. ${ }^{33}$ Although Turkish public opinion on the Iraq war had further declined, his stronger leadership overcame public opinion and party divisions. ${ }^{34}$

The AKP deputies' reluctance to adhere to Erdoğan's preferences in the March 1 vote reflects an important dynamic that is often overlooked in foreign policy analysis studies: how norms and ideas (about the war, in this case) mobilize constituencies and government deputies. While Islamist voters, NGOs, the media, and opinion formers pressured the conservatives in the AKP to say no to the motion, the left pressured the CHP to do the same. Our interviews with high-level decisionmakers of the time suggest that the ideologies of the far right and far left reconciled and created enormous pressure on the MPs. While Islamist conservatives emphasized that invading Iraq was unjust, and called for Muslim solidarity, left-wing constituencies' campaigns used anti-imperialistic and pro-Third World motives. In the end, normative concerns won against the government's political survival motives.

As mentioned earlier, applying a foreign policy model to an important foreign policy decision provides useful insights about policy making in coalition settings, where decisions are products of a broad range of actors and influences playing against each other. In the literature, this area is in the early stages of development and needs further examination. A close look at decision making in the Turkish case helps us understand the conditions that prevented concurrence and deadlock and facilitated a lopsided compromise. To reach generalizations about these conditions, systematic examinations of

\footnotetext{
${ }^{33}$ The most important difference between the March and October 2003 bills was that the latter did not require U.S. soldiers to be admitted to Turkey. Yet, it was costly and required direct Turkish involvement in the war. The October 2003 bill required Turkish troops to fight against resistance in larger cities such as Baghdad, which was one of the most dangerous missions in postinvasion Iraq.

${ }^{34}$ Strong Iraqi opposition to a Turkish military presence in Iraq prevented Turkey from deploying its troops there.
} 
other important foreign policy decisions need to be conducted. Using traditional methods such as elite interviews and process tracing as well as relatively recent tools such as a foreign policy framework offers additional benefits and allows scholars to better understand the political dynamics and intricacies of the decision-making process.

\section{REFERENCES}

Aydın, Mustafa. 2003. "Determinants of Turkish Foreign Policy, and Turkey's European Vocation." The Review of International Affairs 3(2):306-31.

Bölükbaşı, Deniz. 2008. 1 Mart Vakası: Tezkere Krizi ve Sonrası. İstanbul: Doğan Egmont Yayıncılık ve Yapımcılık Tic. AŞ.

Brown, Cameron S. 2007. "Turkey in the Gulf Wars of 1991 and 2003." Turkish Studies 8(1):85-119.

Çuhadar-Gürkaynak, Esra, and Binnur Özkeçeci-Taner. 2004. "Decisionmaking Process Matters: Lessons Learned from Two Turkish Foreign Policy Cases.” Foreign Policy Analysis 5(2):4378.

Efegil, Ertan. 2001. "Foreign Policy-making in Turkey: A Legal Perspective: Turkish Studies 2(1):147-60.

Filkins, Dexter, and Judith Miller. 2003. “Top Political Indicates Turkey May Join US Effort against Iraq." New York Times, February 5.

Gözen, Ramazan. 2005. “Causes and Consequences of Turkey's Out-of-War Position in the Iraq War of 2003.” Turkish Yearbook of International Relations 36:73-99.

Güney, Aylin. 2005. "An Anatomy of the Transformation of the US-Turkish Alliance: From "Cold War" to "War on Iraq"." Turkish Studies 6(3):341-59.

Hagan, Joe D., Philip P. Everts, Haruhiro Fukui, and John D. Stempel. 2001, "Foreign Policy by Coalition: Deadlock, Compromise, and Anarchy." International Studies Review 3(2):169-216.

Hale, William. 2007. Turkey, Iraq, and the United States. London: Saqi Books.

Hermann, Margaret G. 2001. "How Decision Units Shape Foreign Policy: A Theoretical Framework." International Studies Review 3(2):47-81.

Hermann, Margaret G., and Charles F. Hermann. 1989. "Who Makes Foreign Policy Decisions and How: An Empirical Inquiry.” International Studies Quarterly 33(4):361-87.

Hermann, Margaret G., Charles F. Hermann, and Joe D. Hagan. 1987. "How Decision Units Shape Foreign Policy Behavior." Pp. 309-36 in Charles F. Hermann, Charles W. Kegley, Jr., and James N. Rosenau, eds., New Directions in the Study of Foreign Policy. Boston, MA: Allen and Urwin.

Hermann, Margaret G., Thomas Preston, Baghat Korany, and Timothy M. Shaw. 2001. "Who Leads Matters: The Effects of Powerful Individuals." International Studies Review 3(2):83-131.

Hudson, Valerie M. 2005. "Foreign Policy Analysis: Actor-Specific Theory and the Ground of International Relations." Foreign Policy Analysis 1:1-30.

James, Carolyn C., and Özgür Özdamar. 2009. "Modeling Foreign Policy and Ethnic Conflict: Turkey's Policies towards Syria." Foreign Policy Analysis 5(1):475-94. 
Kapsis, James E. 2006. "The Failure of US-Turkish pre-Iraq War Negotiations: An Overconfident United States, Political Mismanagement, and Conflicted Military." Middle East Review of International Affairs 10(3):33-45.

Kardaş, Saban. 2006. "Turkey and the Iraqi Crisis: JDP between Identity and Interest." Pp. 306-330 in Hakan Yavuz, ed., Emergence of a New Turkey: Democracy and the AK Parti. Salt Lake City, UT: University of Utah Press.

Kesgin, Bariş, and Juliet Karboo. 2010. "When and How Parliaments Influence Foreign Policy: The Case of Turkey's Iraq Decision.” International Studies Perspectives 11:19-36.

Kirişçi, Kemal. 2006. "Turkey’s Foreign Policy in Turbulent Times." Chaillot Paper, No 92. Paris, France: Institute for Security Studies.

Makovsky, Alan, and Sabri Sayari. 2000. Turkey's New World: Changing Dynamics in Turkish Foreign Policy. Washington, DC: The Washington Institute for Near East Policy.

Maoz, Zeev, and Bruce Russett. 1993. "Normative and Structural Causes of the Democratic Peace, 1946-1986." American Political Science Review 87(3):624-38.

Özcan, Gencer. 2001. "The Military and the Making of Foreign Policy in Turkey.” Pp. 13-30 Barry Rubin and Kemal Kiriş̧i, eds., Turkey in World Politics: An Emerging Multi-Regional Power. Boulder, CO: Lynne Riener.

Özcan, Mesut. 2008. Harmonizing Foreign Policy: Turkey, the EU and the Middle East. Burlington, VT: Ashgate.

Özcan, Nihat Ali. 1999. PKK: Tarihi, Ídeolojisi ve Yöntemi. Ankara: ASAM Yayınları.

Özcan, Nihat Ali, and Özgür Özdamar. 2009. "Iran’s Nuclear Program and Future of USIranian Relations.” Middle East Policy 16(1):121-33.

. 2010. "Uneasy Neighbors: Turkish-Iranian Relations since the 1979 Islamic Revolution.” Middle East Policy 17(3):101-17.

Putnam, Robert D. 1988. "Diplomacy and Domestic Politics: The Logic of Two Level Games.” International Organization 42(3):427-60.

Robins, Phillip. 2003a. Suits and Uniforms: Turkish Foreign Policy since the Cold War. Seattle, WA: University of Washington Press.

. 2003b. "Confusion at Home, Confusion Abroad: Turkey between Cophenagen and Iraq." International Affairs 79:547-66.

Rubin, Michael. 2005. “A Comedy of Errors: America-Turkish Diplomacy and the Iraq War.” Turkish Policy Quarterly 4(1):69-80.

Rustow, Dankwart, A. 1989. Turkey: America's Forgotten Ally. New York: Council on Foreign Relations Press.

Schmitt, Erik. 2002a. "US Plan for Iraq is Said to Include Attack on Three Sides.” New York Times, July 5, 2002.

. 2002b. "US Plans Massive Invasion of Iraq.” UPI, July, 10.

Tayfur, Fatih, and Korel Göymen. 2002. "Decision Making in Turkish Foreign Policy: The Caspian Oil Pipeline Issue." Middle Eastern Studies 38(2):101-22.

Yanatma, Servet. 2008. "1 Mart'ın üzerinden Beş Yil Geçti; Ancak Muhasebesi Netleşmedi.” Zaman, March 1.

Yetkin, Murat. 2003.”Hükümet Krizi.” Radikal, March 2. 2004. Tezkere: Irak Krizinin Gerçek Öküüü, 2nd ed. Remzi Kitabevi: Istanbul. 


\section{Appendix A: Decision Unit Selector}

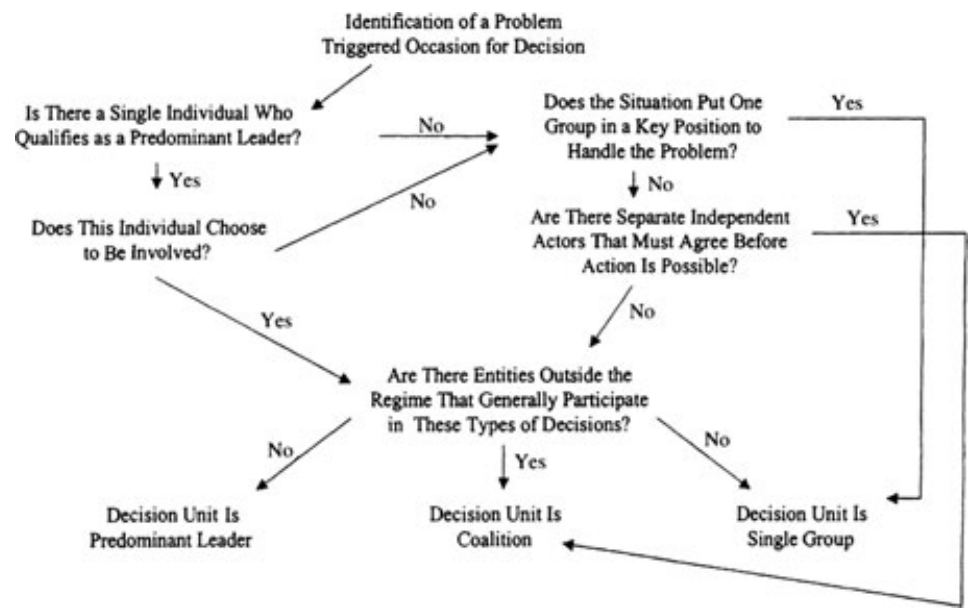

NotE: Adopted from Hermann (2001: 51). 